\title{
Problems Encountered in Translating Cultural Expressions from Arabic into English
}

\author{
Bader S. Dweik $^{1} \&$ Maisa Suleiman ${ }^{1}$ \\ ${ }^{1}$ Department of English, Middle East University, Amman, Jordan \\ Correspondence: Bader S. Dweik, Department of English, Middle East University, Amman, Jordan. Tel: \\ 962-7-9573-0325. E-mail: drdweik@yahoo.com
}

Received: May 30, 2013 Accepted: June 24, 2013 Online Published: September 23, 2013

doi:10.5539/ijel.v3n5p47 URL: http://dx.doi.org/10.5539/ijel.v3n5p47

\begin{abstract}
This study aimed at investigating the problems that Jordanian graduate students majoring in the English language faced when translating culture-bound expressions. To achieve the goal of this study, the researchers selected a random sample that comprised 60 graduate students who were enrolled in the M.A program in three Jordanian universities during the second semester 2009/2010. The researchers designed a translation test that consists of 20 statements which M.A students were asked to translate from Arabic into English. Each statement contained a culture-bound expression based on Newmark's categorization of cultural terms. Proverbs, idioms, collocations and metaphors were extracted from different cultural materials, i.e., legal, historical, religious, social... etc. The researchers also conducted informal open-ended interviews with experts in the field of translation to yield additional information from the experts' point of view regarding these problems, their causes and solutions. The results of the study revealed that graduate students encounter different kinds of problems when translating cultural expressions. These problems are mostly related to: 1) unfamiliarity with cultural expressions 2) failure to achieve the equivalence in the second language, 3) ambiguity of some cultural expressions, 4) lack of knowledge of translation techniques and translation strategies. In light of these results, the researchers recommend narrowing the gap between cultures through adding more courses that deal with cultural differences, cultural knowledge, and cultural awareness, especially in the academic programs that prepare translators.
\end{abstract}

Keywords: problems, translating, cultural, expressions, Arabic/English

\section{Introduction}

\subsection{Background of the Study}

The purpose of translation is communication. Basically human beings use language as the most important means of communication, and language is influenced by people's culture and beliefs whether consciously or unconsciously. Therefore translation involves both language and culture; yet most translation definitions do not directly imply cultural expressions. For instance, Catford (1965) stated that "translation is the replacement of textual material in one language by equivalent textual material in another language." (p. 20). Similarly Savory (1968) maintained that translation is made possible by an equivalence of thought that lies behind its different verbal expressions. Even Newmark (1981) who gave a great importance to cultural elements in his suggestions of methods and procedures still did not indicate culture in his definition. He stated that "translation is a craft consisting in the attempt to replace a written message and/or statement in one language by the same message and/or statement in another language." (p. 7)

In his attempt to define translation and the role of a translator, Nida (1964) took into consideration the cultural elements by stating that "the role of a translator is to facilitate the transfer of the message, meaning, and cultural elements from one language into another and create an equivalent response to the receivers" (p. 13). He also suggested that the message from the source language is embedded by a cultural context.

According to Newmark (1988) foreign cultural expressions include ecological, material, and social cultures. They also include expressions related to social organizations, political, religious, artistic, gestures and habits. Cultural expressions can also be found in proverbs, collocations, phrasal verbs and figures of speech including metaphors.

Gaber (2005) asserted that culture-bound words can be translated by using five different techniques. The first one 
uses "cultural equivalent" words or phrases such as translating "it rains cats and dogs" by its Arabic equivalent "انها تمطر كأفو اه القرب". The second technique is the "functional translation" where the translator uses words/phrases that have the same function in the source language, i.e., translating "hello" as "السلام عليكم". The third technique is "paraphrasing" in which the translator explains in the target language the meaning of the word/phrase in the source language such as translating the word "thesaurus" by "معج الألفاظ المتر ادفة والمتضادة". The fourth technique is "glossing" where the translator gives additional information in a footnote or within the text to explain the cultural word or expression such as explaining the Arabic word "AL-Zakat" by "is one of the 'Five Pillars of Islam,' and is an important religious obligation for Muslims. It requires the giving of an individual's wealth. Historically, it was levied in Islamic countries as a tax upon adult Muslims". The fifth technique is "borrowing" where the translator borrows from the source language the word or phrase and arabize it such as translating "internet" by "نㅣㄹ"

Cultural expressions used in social, religious, geographical, political, literary and media texts constitute a major problematic area in translation especially when the translator belongs to a completely different culture from the author's.

\subsection{Objectives and Questions of the Study}

This study aims at investigating the problems that graduate students majoring in English in Jordanian universities face in translating texts that contain cultural expressions. It is also an attempt to unfold the factors that cause these problems and to give some recommendations to help overcome them. In order to achieve these goals, the study will answer the following questions:

1. What are some of the problems that Jordanian university graduate students majoring in the English language encounter when translating cultural expressions?

2. What are the reasons behind these problems?

\subsection{Significance of the Study}

Many studies have been conducted in the world at large on the problems that translators encounter in translation, but the empirical studies that deal with cultural expressions in the Arab world are relatively small and the focus has been on one particular category such as idioms, proverbs and collocations. Therefore, this study may fill a gap in literature since it aims to investigate the problems taking into consideration all kinds of cultural expressions. It is also of use to professional translators, students of translation, curriculum developers and planners and other cultural organizations concerned with the spread of knowledge via translation. Results of this study and its recommendations for future research may help other researchers who wish to embark on this topic. However, results of this study cannot be generalized beyond the selected sample.

\subsection{Review of Related Literature}

Olk (2003) conducted a study that explored the influence of cultural knowledge on translation performance of German students of English. The sample consisted of 19 German students at a German university. They were asked to translate an English article for publication in the German news magazine Der Spiegel. The text had a significant number of British cultural references, and in order to gain deeper insight into potential knowledge problems the students were asked to think aloud while translating, i.e., to verbalize any thought that came to mind while translating. The study found that the students often lacked sufficient knowledge about British culture to deal with widely-used cultural concepts which led them to use inappropriate solutions. The findings suggested that factual reference sources have an important role in translation activities.

Littlemore (2003) investigated the effect of cultural differences on translating metaphor interpretation. He aimed to find out the ways in which Bangladeshi students interpreted metaphors used by their lecturers during a short course at a British university. Students were asked to interpret a number of metaphors presented in context and to identify the value judgements that were being expressed through these metaphors in these particular contexts. Hofstede's (1980) cultural values questionnaire was administered to identify areas of disparity between the (working) cultures of the Bangladeshi students and their British lecturers. The results showed that the kinds of misinterpretations that the students made of (the evaluative content of) the metaphors appeared in accordance with the cultural differences between both.

Abdel-Fattah and Zughoul (2003) aimed to find the extent to which university English language learners can use English collocations properly and render their meaning. A two-form translation test of 16 Arabic collocations was administered to both graduate and undergraduate students of English. The first form included the English translation in a multiple-choice format whereas the other was given as a free translation task. The findings confirmed that Arab learners of English at all levels face problem in translating English collocations which are basically culture-bound terms. 
Al-Dahesh (2008) explored problems posed to Arab professional translators and Arab translation students when translating idiomatic English phrasal verbs into Arabic, and proposed a number of recommendations for professional translators, lexicographers and pedagogues. Translation tests were conducted to identify types of errors and translational pitfalls. The study revealed that there are in fact many problems encountered when dealing with the phenomenon of idiomatic English phrasal verbs. The most important aspect of such problems is the failure to achieve functional-pragmatic equivalents of such verbs. Literal translation, mistranslating, reducing idioms to sense and breaching of the Arabic language system, along with covertly erroneous errors, such as wrong Arabic collocation, shift of register, incorrect delivery of speech acts, usage of paraphrasing and usage of Arabic colloquial and regional dialects, were the major reasons behind the failure of delivering the appropriate functional pragmatic equivalents of the idiomatic English phrasal verbs listed in the translation tests.

Badawi (2008) investigated the ability of Saudi EFL prospective teachers to translate cultural expressions and to identify the most common strategies. The participants were 43 EFL prospective teachers whose age ranged from 21 to 23 years old. The sample was limited to the fourth year English language majors who were supposed to be well acquainted with English language and translation techniques. The instruments he used were a culture-based translation test and a translation strategy awareness questionnaire. The study revealed that teachers' performance was very poor as reflected by their scores on the culture-based translation test; their translation strategy awareness was very poor and the method of translation was literal.

Alousque (2009) focused on cultural words which require a cultural background to be properly understood and therefore pose translation problems. The challenges in the translation of cultural items and the range of translation procedures used to explain their meaning through the analysis of the lexis from the French cultural domain of cooking was examined. Those problems result from a number of linguistic phenomena, including the different semantic range of the cultural words in the source and the target languages, the absence of the cultural concept in the target language, the loss of meaning and the metaphorical meaning conveyed by many cultural words. The study has revealed the constraints of the translation strategies used to transfer the meaning of cultural units into the target language (loan, functional equivalence, descriptive equivalence, approximate equivalence) and the differences in the conceptualization of reality as reflected by the translation of metaphorical words and expressions from the French domain of cooking. These differences point to a cultural gap which makes the translation of cultural lexis a hard task.

Dweik and Abu-Shakra (2011) investigated the most serious problems that translators face when rendering collocations in religious texts namely, the Holy Quran, the Hadith and the Bible. A purposive sample comprising 35 students enrolled in the M.A translation programs at the universities of Petra, Yarmouk and the University of Jordan was selected. The test consisted of 45 contextually short sentences selected from the above-mentioned three texts and assigned 15 sentences for each religious text. The study revealed that translators encountered problems in lexical and semantic collocations due to the specificity of certain religious collocations that are deeply immersed in the Arabic culture. It also concluded that translators of religious texts should be deeply aware of the nature of lexical and metaphoric collocations, should realize the disparities between Arabic concepts and beliefs and Western ones, and should always take context into consideration.

\section{Method}

\subsection{Sample of the Study}

A sample of 40 students was selected, based on availability, from three Jordanian universities. The demographic background information about the students' general background included social data such as gender, age, nationality, number of years they have worked in translation, and the number of years spent in English speaking countries. Table 1 below shows the demographic characteristics of the participants:

Table 1. Demographic characteristics of the sample

\begin{tabular}{llc}
\hline $\mathbf{1}$ & Sex & No. \\
\hline & Male & 25 \\
& Female & 15 \\
\hline $\mathbf{2}$ & Age & No. \\
\hline & $20-24$ & 4 \\
& $25-29$ & 12 \\
\hline
\end{tabular}




\begin{tabular}{llc}
\hline $30-34$ & 22 \\
& Above 35 & 2 \\
\hline $\mathbf{3}$ & Nationality & No. \\
\hline & Jordanian & 35 \\
& Non-Jordanian & 5 \\
\hline $\mathbf{4}$ & Number of years worked in translation related fields & No. \\
\hline & None & 29 \\
& $0-5$ & 11 \\
& More than 5 & None \\
\hline $\mathbf{5}$ & Number of years spent in a country where English is the first language & No. \\
\hline & None & 35 \\
& $0-5$ & 5 \\
& More than 5 & None \\
\hline $\mathbf{6}$ & Total number of respondents & 40 \\
\hline
\end{tabular}

\subsection{Sampling Procedures}

The sample was selected on grounds of convenience. The researchers approached the three Jordanian universities and asked the students, who were enrolled in English and translation programs, to take the translation test. Additionally, four experts, who taught translation in Jordanian universities, were interviewed in their workplace.

\subsection{Instruments of the Study}

The researchers used two instruments. The first one was a translation test, created specifically to meet the needs of the current study. The test, which included 20 statements, was piloted and pretested before it was administered to the selected sample. The statements contained cultural expressions, based on Newmark's categorization of cultural terms. Proverbs, idioms, collocations and metaphors were taken into account as many of them were considered cultural specific expressions. (See Appendix A and B). Forty copies of the test were distributed along with a cover letter which explained the purpose of the study, and the official approval to carry it out was given to the respondents.

The second instrument was informal open-ended interviews; the researchers interviewed four experts who taught translation courses. Each interview consisted of three questions (see Appendix C). The questions were related to the problems that students encountered, the causes of such problems and solutions that could be given to ease the problems.

\subsection{Validity and Reliability of the Test}

To insure the validity of the test, a panel of four university professors who have teaching experience in linguistics and translation were requested to determine the face and the content validity of the test. They were asked to provide their comments, notes and recommendations on the appropriateness of the content. The professors were responsive and provided the researchers with valuable suggestions and recommendations. Accordingly, some changes were made to the test. For example, one professor recommended adding some collocations and deleting some idioms and proverbs.

For the purpose of achieving a high degree of reliability of the test, a pilot study which aimed to answer the following two questions was conducted.

1. Was the time given to the students enough to translate the 20 statements and to use all the external resources needed?

2. Were the statements clear enough?

The reliability of the test was determined by means of test-retest. The test was administered to ten M.A students who shared the same characteristics of the population. They were asked to take it as homework in order for them to be able to use external resources. After two weeks the test was administered again to the same students.

Data were collected by means of translation test and open-ended interviews. For the test, the participants were 
asked to translate the statements. The total score of the test was 40 marks and the scale of marks was also validated by the panel of experts as follows:

1- Correct answer (CA) was given two marks. The answer was considered correct if the cultural expression was rendered correctly.

2- Acceptable answer (AA) was assigned one mark. The answer was considered acceptable if the cultural expression was rendered correctly, but no further explanation was given if needed including answers that had some slight linguistic error that did not change the meaning.

3- Wrong answer (WA) was given zero mark if the answer failed to render the cultural term and/or committed some fatal linguistic errors that changed the meaning of statements.

4- No Answer (No) was given zero mark.

\section{Results}

\subsection{Results of the Test}

Results of students' performance in the test are presented first in Table 2 below. Answers are presented in four categories: correct answer, acceptable answer, no answer and wrong answer. Results which show frequencies and percentages are presented first and each statement in the test is discussed separately where major errors and problems are highlighted .It is clear that correct answers show lower percentages specially in statement No 1,3 , $4,6,7,8,9,11,12,14,15,16,17,18,19$ and 20 . The statements that show high percentages in wrong answers include statement No 1, 3, 9, 12,13,16 and 19. These problems will be discussed next.

Table 2. Students' translation performance in the Arabic-English test

\begin{tabular}{|c|c|c|c|c|c|c|c|c|}
\hline \multirow{3}{*}{ Statement } & \multicolumn{2}{|c|}{$\mathrm{CA}$} & \multicolumn{2}{|c|}{ A A } & \multicolumn{2}{|c|}{ W A } & \multicolumn{2}{|c|}{ No } \\
\hline & \multicolumn{2}{|c|}{2 Points } & \multicolumn{2}{|c|}{1 Point } & \multicolumn{2}{|c|}{ Zero } & \multicolumn{2}{|c|}{ Answer } \\
\hline & Freq & $\%$ & Freq & $\%$ & Freq & $\%$ & Freq & $\%$ \\
\hline One & 1 & $2.50 \%$ & 11 & $27.50 \%$ & 16 & $40 \%$ & 12 & $30 \%$ \\
\hline Two & 5 & $12.50 \%$ & 31 & $77.50 \%$ & 2 & $5 \%$ & 4 & $10 \%$ \\
\hline Three & 18 & $45 \%$ & 7 & $17.50 \%$ & 11 & $27.50 \%$ & 3 & $7.50 \%$ \\
\hline Four & 17 & $42.50 \%$ & 13 & $32.50 \%$ & 7 & $17.50 \%$ & 2 & $5 \%$ \\
\hline Five & 5 & $12.50 \%$ & 33 & $82.50 \%$ & --- & $0 \%$ & 5 & $12.50 \%$ \\
\hline Six & 2 & $5 \%$ & 3 & $7.50 \%$ & 11 & $27.50 \%$ & 5 & $12.50 \%$ \\
\hline Seven & 7 & $17.50 \%$ & 27 & $67.50 \%$ & 1 & $2.50 \%$ & 3 & $7.50 \%$ \\
\hline Eight & 5 & $12.50 \%$ & 31 & $77.50 \%$ & 1 & $2.00 \%$ & 4 & $10 \%$ \\
\hline Nine & 15 & $37.50 \%$ & 4 & $10 \%$ & 17 & $42.50 \%$ & 9 & $22.50 \%$ \\
\hline Ten & 20 & $50 \%$ & 8 & $20 \%$ & 3 & $7.50 \%$ & 2 & $5 \%$ \\
\hline Eleven & 26 & $65 \%$ & 10 & $25 \%$ & 2 & $5 \%$ & 2 & $5 \%$ \\
\hline Twelve & 10 & $25 \%$ & 16 & $40 \%$ & 12 & $30 \%$ & 3 & $7.50 \%$ \\
\hline Thirteen & 24 & $60 \%$ & 1 & $2.50 \%$ & 11 & $27.50 \%$ & 4 & $10 \%$ \\
\hline Fourteen & 8 & $20 \%$ & 24 & $60 \%$ & 4 & $10 \%$ & 6 & $15 \%$ \\
\hline Fifteen & 4 & $10 \%$ & 20 & $50 \%$ & 10 & $25 \%$ & 3 & $7.50 \%$ \\
\hline Sixteen & 9 & $22 \%$ & --- & $0 \%$ & 28 & $70 \%$ & 7 & $17.50 \%$ \\
\hline Seventeen & 5 & $12.50 \%$ & 16 & $40 \%$ & 12 & $30 \%$ & 10 & $25 \%$ \\
\hline Eighteen & 22 & $55 \%$ & --- & $0 \%$ & 8 & $20 \%$ & 7 & $17.50 \%$ \\
\hline Nineteen & 9 & $22.50 \%$ & 7 & $17.50 \%$ & 17 & $42 \%$ & --- & $0 \%$ \\
\hline Twenty & 1 & $2.50 \%$ & 27 & $67 \%$ & 8 & $20 \%$ & 4 & $10 \%$ \\
\hline
\end{tabular}

$C A=$ Correct Answer $\quad$ AA $=$ Acceptable Answer $\quad$ WA $=$ Wrong Answer $\quad$ No $=$ No Answer 
Statement (1)

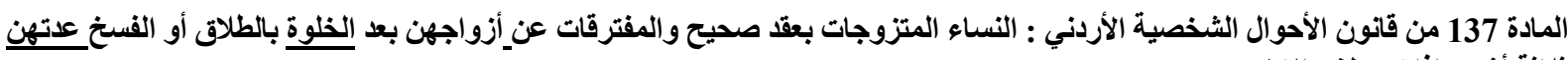
ثلاثة أشهر إذا كن بلغن الإياس.

As shown in Table 2, 12 (30\%) of the respondents did not provide any translation for this statement. This can be related to specialized legal and religious terms in it. Only $1(2.5 \%)$ provided a correct translation in addition to providing a footnote explaining the term (Iddat) which has no one-to-one equivalent in English.

In Islam, Iddah or Iddat (Arabic: العدة; period of waiting) is the period a woman must observe after the death of her spouse or after a divorce, during which she may not marry another man. The period, three months after a divorce and four months and ten days after the death of a spouse, is calculated on the number of menses that a woman has. Iddah was intended to ensure that the male parent of any offspring produced after the cessation of a nikah would be known.

Meanwhile, $11(27 \%)$ of the respondents rendered an acceptable translation without providing any extra information. This can be a result of unfamiliarity with this translation technique or it might be that they did not find it necessary to offer such an explanation. Only $16(40 \%)$ of the respondents provided wrong translation such as "grace period", "waiting period", "three months pause". In addition to the term (Iddat), the term "خلوة" (Khulwa), was translated by some as "consummation of marriage" while actually this presents a problematic area even for religious judges and in religious court, as until the moment they did not agree about the "privacy" and if it means that the marriage was consummated or not.

Statement (2)

تعتزم الإمارات إلزام الثركات والمؤسسات المالية الإسلامية بدفع زكاة مالهيامع نهاية كل سنة مالية.

This statement was translated correctly by 5 (12.5\%) of the respondents which means using the glossing technique for the term "زاة (Zakat) and providing a footnote that explains the meaning of it as in "UAE intends to oblige Islamic financial companies and institutions to pay *Zakat el mal at the end of every fiscal year."

Zakah or Zakat El-Mal is an annual tithe on one's wealth or possessions. Also, Zakah is one of Islam's obligations and one of its five main pillars. On the other hand, 31 (77.5\%) of them used the glossing technique or called it "Islamic Tax" without providing any further information about the meaning of the term "Zakat", probably some of the respondents assumed that this is a well known term that did not need explanation.

\section{Statement (3)}

$$
\text { أماط البحث الجنائى اللثام ،أمس، عن اخطر العصابات المتخصصة في سرقات السيارات في الأردن. }
$$

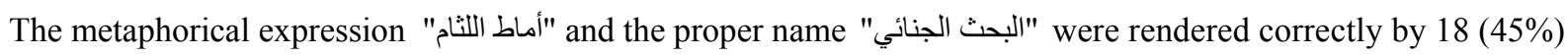
of the respondents. They used a similar metaphorical expression and replaced the proper name by the correct equivalence as in "The Criminal Investigation Department (CID) yesterday unveiled the most dangerous gangs specialized in stealing cars in Jordan." Table 2 shows that 7 (17.5\%) of them rendered an acceptable translation without using a metaphorical expression as in "caught, arrested, revealed, found". Yet, 11(27.5\%) provided wrong translation for the proper name "البحث الجنائي" such as: "the forensic police", "policemen", "criminal police", "police department".

\section{Statement (4)}

\section{أقدم لغة مكتوبة معروفة في بلاد ما بين النهرين كاتت السومرية.}

The table shows that the terms "السومرية" and "الاد ما بين النهرين" were translated correctly by 17 (42.5\%) as in "Sumerian was the oldest written language in Mesopotamia". Only 13 (32.5\%) provided an acceptable translation by replacing "Mesopotamia" by "Iraq" which cannot be totally wrong but still this is unfaithful to translation because the author of the source text used it for an intended meaning. Also, 7 (17.5\%) used literal translation such as "the country between the two rivers", or by using transliteration such as "Al-Sumariyya Language"

\section{Statement (5)}

$$
\text { يعتبر المنسف الطبق الرئيسي في المناسبات الأردنية. }
$$

The kind of food mentioned in this statement is a material cultural term. As Table 2 shows, only 5 (12.5\%) rendered it correctly by using both glossing and a footnote as in "* Mansaf is the main dish in Jordanian occasions". Mansaf (Arabic, منسف) is a Jordanian dish. Today it has been adopted as the national dish of Jordan, made of lamb cooked in a sauce of fermented dried yogurt and served with rice. Meanwhile, $33(82.5 \%)$ used only the glossing technique although it would be difficult for a tourist who is interested in reading about Jordan 
to figure out what Mansaf can be "kind of snacks, sweets, soup... etc".

\section{Statement (6)}

تثير الاراسات إلى أن الأردن يشهذ وفق الإحصائيات الرسمية حوالي 25 جريمة شرف سنويا.

The term "honour killing crimes" is widely used lately in the newspapers and the reports of some international organizations, so many respondents found it unnecessary to add extra information which in this case can be reasonable. This statement was translated correctly by $21(52 \%)$ as in "According to studies and as per official statistics Jordan witnesses about 25 honour killing crimes annually". Meanwhile, 11 (27.5) provided wrong translation and sometimes added a footnote that was not correct such as "dignity crimes", "murder cases related to adultery", "crimes of passion", "sharaf crimes: illegal relation between a man and woman is a crime".

\section{Statement (7)}

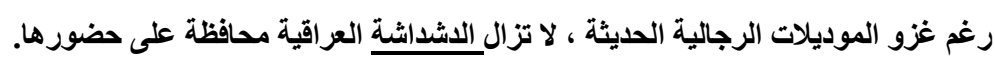

Although the word "الدشداشنة is a known figure in Arabic language and culture, it is still not known for a foreigner so it will need clarification. Only $7(17.5 \%)$ translated it correctly by providing the needed information as in "Although men-modern fashions are prominent in Iraq, Iraqi *dishdasha is still worn". A thawb or thobe (Arabic: ثوب thawb), dishdasha (شداثة dišdāšah), kandura (كندورة kandūrah) khameez (قميص qamīs), is an ankle-length garment, usually with long sleeves, similar to a robe. While $27(67 \%)$ translated it in an acceptable way using the glossing technique without providing a footnote, only one (2.5\%) provided a wrong translation using the word "gowns" to convey the meaning.

\section{Statement (8)}

$$
\text { أكدت المحكمة قرار حظر النقاب في الجامعات المصرية. }
$$

The word "النقاب" was rendered correctly by 5 (12.5\%); they clarified that it is a veil to cover the face as in: The court confirmed the decision to ban *AL niqāb in Egyptian universities. *A niqāb (Arabic: نقياب) is a veil which covers the face, worn by some Muslim women as a part of the hijāb. However, 31 (77.5\%) translated it as "veil" without indicating that the face cover was banned and not the head cover. Such a mistake might result in an objection made by the Egyptian court or authorities for changing the facts.

\section{Statement (9)}

$$
\text { نظرة المجتمع قد تدفع باللقيط للانطو اء. }
$$

The word "اللقيط" was translated correctly by 15 (37.5\%) as in "The image drawn by the society for a foundling may force him to solitude". While 17 (42.5\%) provided wrong translation such as "the bastard", "illegal person", "orphan who for unknown parents", "abandoned baby", only $4(10 \%)$ provided an acceptable translation by paraphrasing it as "a child or a baby for unknown parents".

\section{Statement (10)}

$$
\text { ابدأ بالعائلة فالأقربون أولى بالمعروف. }
$$

This expression derived from a religious text was rendered correctly by 20 (50\%) by providing the English equivalent expression "proverb" as in "Start with your family since charity begins at home". However, $9(22.5 \%)$ did not provide any translation while $3(7.5 \%)$ provided wrong translations such as "family is more blood-related to you", "blood is stronger than water".

\section{Statement (11)}

$$
\text { ما أن رآنا حتىشمر عن ساعديه وبدأ بالمساعدة. }
$$

The expression "شمر عن ساعديه was translated correctly by 26(65\%). They simply conveyed the meaning of the expression in English as in "Once he saw us, he started helping". Still $4(10 \%)$ provided an acceptable translation by giving a close but indirect translations such as "he offered his help", "he suggested to give us a hand", "he was willing to help". Only $2(5 \%)$ provided a literal translation as in "he pulled up his sleeves and helped". Such expressions can be tricky and might lead the respondents to avoid simple, direct and brief translation.

\section{Statement (12)}

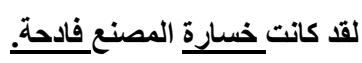

The Arabic collocation was rendered correctly by 10 (25\%) by using an appropriate collocation in English such as "great loss", "grave loss", and "catastrophic loss". Meanwhile $16(40 \%)$ provided acceptable translations as in "tragic loss", "major loss", "huge loss", "very big". Only 12 (30\%) rendered wrong translation such as "fatal 
loss", "serious loss". The adjective "fatal" which is "فادحة أو فادح" collocates in Arabic with both nouns in Arabic "خطأ" and "خسارة" but it is not the same in English where "fatal" collocates with "mistake".

\section{Statement (13)}

$$
\text { أوردت الصحف أن الجندي البريطاني قتل بنيران صديقة. }
$$

The collocation "نيران صديقة" is widely used in the news reports and headlines, so 24 (60\%) were familiar with it and rendered it correctly as in "Newspapers reported that the British soldier has been killed by a friendly fire". On the other hand, 11 (27.5) provided wrong translations as in "by the coalition forces", "by a British soldier", and sometimes they adopted literal translations as in "by his girlfriend", "by a friend of his".

\section{Statement (14)}

$$
\text { يبدو أن "إسرائيل" تضرب بعرض الحائط جميع القرارات الدولية. }
$$

This expression "تضرب بعرض الحائط" was translated correctly by 8 (20\%) by using equivalent expressions that are used in English as in "Israel seems to flout all international resolutions", "Israel throws all international resolutions out the window", "Israel has ears of mud...". Meanwhile $24(60 \%)$ paraphrased it in an acceptable way as in "Israel does not care...", "Israel seems to be careless about...", "Israel ignores..." At the same time only $4(10 \%)$ gave wrong translations using either literal translation such as "Israel throws to the wall..." or by not being objective and adding their personal impression as in "Israel as usual ignores..."

\section{Statement (15)}

كان لا بـ له من التيمم لأداء الصلاة.

The religious term "التيمم was translated correctly by only 4 (10\%). They combined the glossing technique and the footnotes needed in such a case where an equivalence does not exist, as in "He had to perform *Al-tayammum to pray". Tayammum (Arabic: تيمم) refers to the dry ablution in Islam using sand or dust, which may be performed in place of wudu (وضوء), only if no clean water is readily available. On the other hand, 20 $(50 \%)$ used only one technique which is the glossing without providing any further explanation. This makes it hard for the reader to understand what exactly he has to do in order to pray. Moreover, 10 (25\%) provided wrong translations such as "put dust in himself", "wash with dirt", "purify with sand". Usually if religious terms have no equivalent in the target language, a further explanation is necessary. Assuming that the reader is familiar with such terms can result in poor translation.

\section{Statement (16)}

$$
\text { يذكر الإسلام عن النبي سليمان أنه كان قادرا على فهم لغة الطيور والنمل. }
$$

The proper name "سليمان" was translated by the equivalent name in English "Solomon" by only 9 (22.5\%). However, 28 (70\%) transliterated it such as "Sulaiman", "Sulayman", "Suleiman", "Solaiman" which is in this case considered to be wrong because a foreigner might think that this is a proper name for another prophet or so.

\section{Statement (17)}

$$
\text { يرى البعض أن صفة عانس فيها إساءة لمن فاتهن قطار الزواج. }
$$

The metaphorical expression "من فاتهن قطار الزواج was translated correctly by 5 (12.5). By replacing it either with a similar metaphorical expression or with a phrase that conveys the message such as "missed the train of marriage", "missed the age of marriage". Meanwhile $16(40 \%)$ provided acceptable translations by paraphrasing it such as "who did not get married", "a woman who had never been married". Only 12 (30\%) provided wrong answers such as "missed the opportunity to get married", "did not have the chance to get married", "did not find a husband".

\section{Statement (18)}

$$
\text { منظمة العفو الدولية تطالب القوات السعودية واليمنية بحماية المدنيين في صعدة . }
$$

The "organizational name" "منظمة العفو الدولية" was translated correctly by 22 (55\%) using the equivalence in English "Amnesty International" while $10(25 \%)$ skipped translating it. On the other hand $8(20 \%)$ provided wrong translations either by literally translating it or trying to guess the meaning without going back to a reliable resource as in "Forgiveness International Organization", "International Association for Amnesty".

\section{Statement (19)}

$$
\text { كيف تستطيع فتاة أن تثكو والدها في المحكمة وهو وليها والقائم على أمرها. }
$$

The cultural religious terms "وليها و القائم على أمرها" was translated correctly by using the closest equivalence in 
English which is "guardian" by 9 (22.5\%). However, 17 (42.5\%) provided wrong translations for it based on what a guardian means for them such as "her authority", "her provider", "her ruler", "her supporter", "her master". Only $7(17.5 \%)$ provided an acceptable translation by paraphrasing it as in "while he is her father and the one responsible". In addition, $7(17.5 \%)$ decided to skip translating it.

\section{Statement (20)}

Only 1 (2.5\%) rendered the word "لب correctly by using the footnote technique to explain it, as in "We have the best quality Egyptian *seeds for exportation". Egyptian seeds are roasted and salted watermelon seeds. They are one of the traditional Egyptian snacks. While $27(67.5 \%)$ used the glossing technique without providing any further information "Lib" or translated it into "seeds" or "nuts" also without providing any extra information, only $8(20 \%)$ provided wrong literal translation such as "pulp".

The results of the test show that most of the respondents encountered problems when they had to deal with cultural expressions. These problems were mainly about finding the acceptable equivalent expression and using the proper techniques of translation to render the meaning.

\subsection{Results of the Interviews}

The first expert mentioned that the main problem in translating a culture-specific expression is that it usually has an idiomatic meaning which should be memorized. Meanwhile, the second expert stated that "the very name of "culture-specific expressions" or "cultural expressions" indicates the what and the why of their problem. They are simply difficult to comprehend and/or to translate because they are specific to a given culture in terms of their linguistic structure, semantic denotation and, more significantly, their socio-cognitive relevance". Moreover, the third expert indicated that the main problem in translating cultural expressions is defining them. He explained that many students do not have a clear definition of cultural expressions which makes it difficult to recognize and understand and later render them in the second language. For the fourth expert, the students' inability to understand the background of the idiom is one of the main problems. He added that "This is the core of the problem. When a student does not know the background of the idiom, then he will not understand its usage. The issue here is not the wording but it is the context itself. In some cases it is the matter of the words included in the idiom. This is of course attributed to students' weakness in English". He added that in many cases the weak cultural background of the students even in the Arab context makes them unable to guess the equivalent context.

The translation teachers and professors had their own point of view regarding the reasons that might stand behind the poor translations of some cultural texts. For instance, the first expert mentioned that "translation trainees in Jordan are generally weak in both English and Arabic. Their world knowledge is also poor. Therefore, they have to take an entrance exam in which not only the two languages concerned should be tested but also their cultural and world knowledge". He believed that translation should be studied by people who have encyclopedic knowledge. He also added that "Culture-specific expressions are of course more difficult than ordinary plain language because they are deeply rooted in culture and often do not have literal meaning; rather, they have an idiomatic one and they are usually underestimated by both translation trainers and trainees". The second expert gave some examples to explain the reasons behind the problems in translating cultural expressions. He stated that "On the level of structure, take these examples in Arabic and imagine their denotations, apart from their pragmatic connotation and relevance, if literally rendered into English على راسي؛ تكرم؛ ولو؛ السلام عليكم؛ ما تثوفوفي These expressions that are very frequently used in different Arab communities can be extremely difficult to translate, or even comprehend by a British readership. This problem is certainly posed on the level of semantic denotation, which results in the misunderstanding of the meaning(s) of such expressions as intended in actual verbal communication, i.e., in their relevant (pragmatic) context of use".

For the third expert, lack of cultural awareness and lack of cultural interaction can stand behind these problems. He gave the word "Donkey" as an example and explained that in the Arab culture if you call someone a donkey, he will get upset and feel insulted because it has a bad connotation and it means idiot or stupid, while in the western culture the word donkey is used to describe a hard working person which is positive and respectful. He added that lack of knowledge of translation strategies and theories among students could also be one of the main reasons behind the problems they encounter. Meanwhile, the fourth expert stated that "the main reason is the lack of our students' communication with other cultures. People think that through technology our students are strongly in touch with the cultures of others, but as a matter of fact they are not. This makes students much behind understanding the cultural contexts of others. This may include problems related to (a) Ecology (environment, climate, weather, geographical features etc), (b) Social culture and (c) Religious culture". 


\section{Discussion}

Results related to problems encountered by graduate students while translating cultural expressions indicated that most of the students found it difficult to achieve the equivalence or the equivalent effect of the cultural expressions used in the tests. This result agreed with Newmark (1988) as he stated that "the more culturally remote in time and space a text, the less is equivalent effect even conceivable unless the reader is imaginative, sensitive and steeped in the SL culture" (p. 49). This finding also agreed with Al-Dahesh (2008) who found that failure to achieve the equivalence is one of the most important problems.

The results also indicated that adopting and deciding the appropriate translation technique was another problem that students encountered. Many students either used literal translation or used glossing technique without giving any footnote or explanation for the reader. It was also shown that in many cases the students depended on the guessing technique which means depending on the context to figure out the meaning. Despite the importance of the context, it might not unfortunately be useful when it comes to cultural expressions because the words in an idiom for instance are most of the time used totally out of context. This result agreed with Badawi (2008) who found that literal translation and guessing strategies were prevalent among EFL Saudi prospective teachers. The findings indicated that the students were highly influenced by their culture and this was reflected in their translation. Cultural differences play a major role in making the translation a hard task for translators in general and students in particular.

Furthermore, results regarding the reasons behind these problems pointed out that lack of cultural awareness was a major reason behind these problems. This finding agreed with Olk (2002) whose study indicated that the students often lacked sufficient knowledge about British culture which caused them to use inappropriate renditions.

The results indicated that unfamiliarity with translation strategies could also stand behind these problems. This finding agreed with Al-Dahesh (2008) who found that literal translation, mistranslating, reducing idioms to sense and breaching of the Arabic language system, along with covertly erroneous errors, such as wrong Arabic collocation, shift of register, incorrect delivery of speech acts, usage of paraphrasing and usage of Arabic colloquial and regional dialects, were the major reasons behind the failure of delivering the appropriate functional pragmatic equivalents of the idiomatic English phrasal verbs listed in the translation test.

The results also illustrated that lack of researching skills was a reason for their inability to get the needed information about the cultural expression. It also indicated that the huge gap between both cultures was one of the reasons for their poor translation. This agreed with Nida (1964) who stated that "no translation that attempts to bridge a wide cultural gap can hope to eliminate all traces of the foreign setting” (p. 167).

\section{Conclusion}

The data obtained by means of test and interviews indicated that M.A students encountered many problems while translating cultural expressions such as failure to achieve the appropriate equivalence and failure to use the proper techniques in translation. Literal translation and cultural influence resulted in the poor performance of the students in the test. Professors elaborated on the reasons behind these problems and through their answers it was clear that unfamiliarity with both cultures and the improper translation techniques and strategies were major reasons for the poor translation.

Almost all the participants in the interviews had agreed that familiarizing students with their own culture and the foreign culture should be a must, and this can be done by offering extra courses that deal with cultural situations and contexts and by providing chances for a better cultural interaction between native language speakers of both languages.

\section{References}

Abdel-Fattah, H., \& Zughoul, M. (2003). Translational collocational strategies of Arab learners English. Babel, 49(1), 57-77.

Al-Dahesh, A. (2008). Translating idiomatic English phrasal verbs into Arabic (PhD Dissertation). University of Western Sydney. Retrieved from http://handle.uws.edu.au:8081/1959.7/26979

Alousque, I. (2009). Cultural domains: Translation problems. Revista de Linguistica y Lenguas Aplicadas, 4, 137-145.

Badawi, M. (2008). Investigating EFL prospective teachers' ability to translate culture-bound expressions. Retrieved from ERIC database, (ED503396).

Catford, J. C. (1965). A linguistic theory of translation. London: Oxford University Press. 
Dweik, B., \& Abu-Shakra, M. (2011). Problems of translating collocations in religious texts from Arabic into English. The Linguistics Journal, 5(1), 5-44.

Gaber, J. (2005). A textbook of translation: Concept, method, practice. Al-Ain: University Book House.

Littlemore, J. (2003). The effect of cultural background on metaphor interpretation. Metaphor and Symbol, 18(4), 273-288. http://dx.doi.org/10.1207/S15327868MS1804_4

Newmark, P. (1981). Approaches to translation. Oxford: Oxford University Press.

Newmark, P. (1988). A Textbook of translation. Herdford-shire: Prentice Hall.

Nida, E. (1964). Toward a science of translating. Leiden: E. J. Brill.

Olk, H. (2003). Cultural knowledge in translation. ELT, 57(2), 167-174. http://dx.doi.org/10.1093/elt/57.2.167

Savory, T. (1968). The art of translation. London: Jonathan Cape Ltd.

\section{Appendices}

\section{Appendix A. Arabic-English Test}

ترجم ما يلي إلى اللغة الإنجليزية:

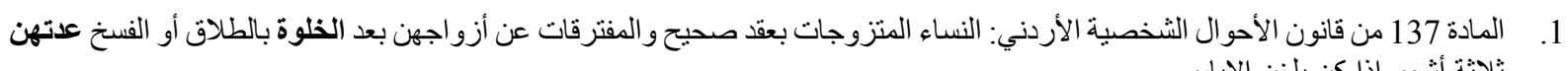
ثلاثة أشهر إذا كن بلغن الإياس.

أعتزم الإمار أقدات إلز ام الثركات و المؤسسات المالية الإسلامية بدفع زكاة مالها مع نهاية كل سنة مالية.

تثبر الدراسات إلى أن الأردن يشها وفق الإحصائيات الرسمية حو الي 25 جريمة شرف سنويا.

رغم غزو الموديلات الرجالية الحديثة ،لا تزال الدشداشة العر اقية محافظة على حضور ها.

أكدت المحكمة قرار حظر النقاب في الجامعات المصرية.

10. ابدأ بالعائلة، فالاقربون أولى بالمعروف.

11. ما أن رآنا حتى شمر عن ساعديه وبدأ بالمساعدة.

12. لقد كانت خسارة المصنع فادحة.

13. أوردت الصحف أن الجندي البريطاني قتل بنيران صديقة.

14. يبدو أن اسر ائيل تضرب بعرض الحائط جميع القرارات الدولية. 
18. منظمة العفو الدولية تطالب القوات السعودية و اليمنية بحماية المدنيين في صعدة .

19. كيف تسنطيع فتاة أن تشكو و الدها في المحكمة و هو وليهاو القائم على

20. يوجد لدينا أفضل أنواع اللب المصري للتصدير.

\section{Appendix B. Model Translation}

1-Article 137 of the Jordanian law of civil status: Iddah (Note 1) for those women married under a valid contract, if in menopause, and separated from their husbands by divorce or disengagement after the privacy is three months.

2-UAE intends to oblige Islamic financial companies and institutions to pay Zakat el mal (Note 2) at the end of every fiscal year.

3-The Criminal Investigation Department (Note 3) unveiled yesterday the most dangerous gangs specialized in stealing cars in Jordan.

4-Sumerian (Note 4) was the oldest written language in Mesopotamia (Note 5).

5-Mansaf (Note 6) is the main dish in Jordanian occasions.

6-According to studies and as per official statistics Jordan witnesses about 25 honor killings crimes (Note 7) annually.

7-Although men-modern fashions are prominence in Iraq, Iraqi dishdasha (Note 8) is still worn.

8-The court confirmed the decision to ban AL niqāb (Note 9) in Egyptian universities.

9-The image drawn by the society for a foundling (Note 10) may force him to solitude.

10-Start with your family since Charity begins at home (Note 11).

11- Once he saw us, he started helping.

12- The factory has incurred a big loss.

13-Newspapers reported that the British soldier has been killed by a friendly fire (Note 12).

14-Israel seems to flout (Note 13) all international resolutions.

15-He should have performed tayammum (Note 14) to pray.

16-Islam says that Prophet Solomon (Note 15), peace be upon him, was known to be able to understand the language of birds and ants.

17-Some people believe that it is offensive to describe those who missed the opportunity to marry as "spinsters" (Note 16).

18-Amnesty International (Note 17) demands the Saudi and Yemeni forces protect civilians in Sa'ada (Note 18).

19-How can a girl file a complaint against her father in a court for preventing her from marriage, whilst being her guardian.

20-We have the best quality Egyptian seeds (Note 19) for exportation.

Appendix C. Open-Ended Interview Questions - for Experts

Informal interviews 
Open-ended questions:

1- Based on your experience, what are some of the problems that students face when translating cultural expressions?

2- What do you personally think the reasons behind these problems?

3- In your opinion, what can be done to ease these problems and facilitate the translation task for the students?

\section{Notes}

Note 1. In Islam, iddah or iddat (Arabic: العدة; period of waiting) is the period a woman must observe after the death of her spouse or after a divorce, during which she may not marry another man. The period, three months after a divorce and four months and ten days after the death of a spouse, is calculated on the number of menses that a woman has. Iddah was intended to ensure that the male parent of any offspring produced after the cessation of a nikah would be known.

Note 2. Zakah is an annual tithe on one's wealth or possessions. Also, Zakah is one of Islam's obligations and one of its five main pillars.

Note 3. The Criminal Investigation Department (CID) is the premier investigative agency and staff authority for criminal investigation matters within the Jordanian Police Force.

Note 4. Sumer is a civilization and a historical region in Southern Mesopotamia, Iraq. It is the earliest known civilization in the world and is known as the cradle of civilization.

Note 5. is a toponym for the area of the Tigris-Euphrates river system, along the Tigris and Euphrates rivers, largely corresponding to modern Iraq, (Note 2) as well as some parts of northeastern Syria, (Note 2) some parts of southeastern Turkey, (Note 2) and some parts of the Khūzestān Province of southwestern Iran.

Note 6. Mansaf (Arabic, منسف) is a Jordanian dish. Today it has been adopted as the national dish of Jordan, made of lamb cooked in a sauce of fermented dried yogurt and served with rice.

Note 7. An honor killing (also called a customary killing) is the murder of a family or clan member by one or more fellow family members, where the murderers (and potentially the wider community) believe the victim to have brought dishonor upon the family, clan, or community.

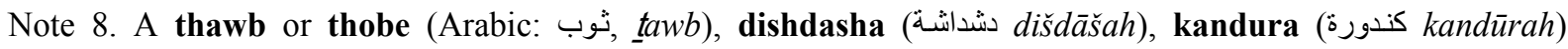
khameez (قميصqamiṣ), or suriyah in Libya, is an ankle-length garment, usually with long sleeves, similar to a robe.

From Wikipedia, the free encyclopaedia: http://en.wikipedia.org/wiki/Thawb

Note 9. A niqāb (Arabic: نقاب) is a veil which covers the face, worn by some Muslim women as a part of sartorial hijāb.

Note 10. A deserted or abandoned child of unknown parentage.

Note 11. An idiom that means you should try to help your family and friends before you help other people.

Note 12. Is an expression meaning fire from one's own side or allied forces, as opposed to fire coming from enemy forces, and was a term originally adopted by the United States military.

Note 13. To express contempt for the rules by word or action; To scorn

en.wiktionary.org/wiki/flout

Note 14. Tayammum (Arabic: تيمم) refers to the dry ablution in Islam using sand or dust, which may be performed in place of wudu or ghusl, only if no clean water is readily available.

From Wikipedia, the free encyclopaedia: $\mathrm{http}$ ://en.wikipedia.org/wiki/Tayammum

Note 15. Prophet Sulaiman (Solomon) was the youngest son of Prophet Dawud (David, peace be upon him). He was born in Jerusalem. The name of his mother was Saba. As he was a talented fellow with versatile gifts, his father made him his heir.

From ISLAM 101: http://www.islam101.com/history/people/prophets/sulaiman.htm

Note 16. Socially, the term is usually applied only to women who are regarded as beyond the customary age for marriage, and is sometimes considered an insulting term, more degrading than the term "bachelor" for males.

From Wikipedia, the free encyclopaedia: http://en.wikipedia.org/wiki/Spinster 
"Spinster" is "a single woman who has remained single beyond the conventional age for marrying," according to Miriam Webster.

Note 17. Amnesty International is a worldwide movement of people who campaign for internationally recognized human rights for all.

From the website of the Amnesty International: http://www.amnesty.org/en/who-we-are

Note 18. Also spelled Saada, is a town, north-western Yemen, in the mountainous Yemen Highlands.

Note 19. Egyptian roasted salted watermelon seeds is one of the traditional Egyptian snacks.

\section{Copyrights}

Copyright for this article is retained by the author(s), with first publication rights granted to the journal.

This is an open-access article distributed under the terms and conditions of the Creative Commons Attribution license (http://creativecommons.org/licenses/by/3.0/). 